\title{
Biofuel research: perceptions of power and transition
}

\author{
Lena Partzsch
}

\begin{abstract}
Whether biofuels represent a sustainable innovation, a creative alternative, or a gold rush, very much depends on our perception of power and change with regard to sustainability. This article provides an overview of existing understandings of power in the research on biofuels, including positive perceptions that often lead to more optimistic evaluations of biofuels. It exposes the diversity with which one can understand power through three ideal type concepts: "power with," "power to," and "power over". Integrating these concepts in one power framework allows for examining how the three dimensions interrelate with each other and developing the contours of a power lens on biofuel governance and research. With the 2007-2008 food price crisis, critics re-politicized the governance of biofuels. Several farmer associations have completely turned against biofuels. The article argues that this rejection of biofuels is due to a limited perception of power as a coercion and manipulation (power over). While the current governance of biofuels basically reproduces systems and positions, we should start to more seriously and intensively ask questions of where, when, and how the governance of biofuels may also allow for "green" resistance (power to) and collective empowerment (power with).
\end{abstract}

Keywords: Biofuels, Governance, Power

\section{Introduction}

Whether biofuels represent a sustainable innovation, a creative alternative or a gold rush [1], very much depends on our perception of power and change with regard to sustainability. This leads to the challenge of how to conceptualize these understandings. I gather diverse perceptions of power and illustrate them for biofuel research. The aim is to initiate a broader, more comprehensive debate across ontological and epistemological differences in this field of research. To begin the discussion, I introduce key components of the debate by identifying different perceptions of power that are common to research on biofuels along three ideal type conceptions:

- Power with means collective empowerment through convincing and learning with and from each other. It refers to processes of developing shared values, finding common ground, and generating collective

Correspondence: lena.partzsch@ifp.uni-freiburg.de

Sustainability Governance, Institute of Environmental Social Sciences and Geography, University of Freiburg, Tennenbacher Strasse 4, D-79106 Freiburg, Germany

(c) The Author(s). 2017 Open Access This article is distributed under the terms of the Creative Commons Attribution 4.0 International License (http://creativecommons.org/licenses/by/4.0/), which permits unrestricted use, distribution, and reproduction in any medium, provided you give appropriate credit to the original author(s) and the source, provide a link to the Creative Commons license, and indicate if changes were made. strengths [2]. Based on this understanding of power, biofuels can potentially be a sustainable innovation that serves the common good (climate protection, energy security, regional development, etc.) (e.g., [3, 4]).

- Power to corresponds to the ability of agents "to get things done" [5]. While Pitkin [6] defines power to as non-relational, Barnett and Duvall [7] define power to as tied to social relations of constitution that define who the actors are, along with their capacities and practices. ${ }^{1}$ Scholars, who take a perspective of power to, may highlight the agency of producing biofuels as a creative alternative in hitherto fossil fuel-dependent societies (e.g., [8, 9]).

- Power over describes the direct and indirect ability of powerful actors, structures, and discourses to influence the actions and even the thoughts of others. It is based on power concepts by Dahl [10], Bachrach and Baratz [11], and Lukes [12], among others. I also discuss concepts of discursive power under this category (e.g., [13, 14]), while I am aware that these concepts partly fall under the category of power to [7]. From a perspective of power over, biofuels can be seen as a gold rush: While everybody

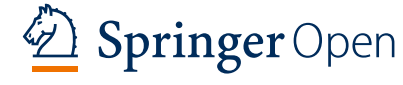


expected sudden wealth in this new field, there are very few winners and many losers (e.g. $[15,16])$.

I chose this tripartite approach as a framework for my article, because it is most comprehensive and makes an extension of the power discussion on biofuels possible. At the same time, the framework allows for the discussion of the well-known grouping of the four "faces of power" under the category of power over [17, 18]. I will argue that in the research on biofuels, the understandings of power as power with and power to tend to prevail, even when they are not made explicit. This means that scholars have overemphasized the potential of biofuels as a creative alternative to fossil fuels and sustainable innovation for rural development. Concepts of power over have only more recently been applied, specifically since research has started to explicitly issue power. This has, in particular, been used to explain why any process of governing biofuels (biofuel governance) did not lead to urgent sustainability transitions, and why the biofuel boom should rather be seen as a gold rush. Scholars have demonstrated that the development of biofuels markets benefitted large companies and conglomerates [19]. Critical and post-structuralist perspectives have helped to understand this development by exploring structures and discourses favoring them [20]. Scholars have used Foucault's concepts to outline how scientific knowledge practices render the very essence of problems (and solutions) raised on the biofuel agenda [21, 22].

This article involves first of all implicit and explicit understandings of power (how do biofuel researchers think and talk about power?). These understandings are expressed in empirical research, as I will demonstrate below, and they hence also allow for an illustration of the practice of biofuel governance (how is power exercised in and through biofuel governance?). This makes the article also relevant for political practice. We should understand, not only in theoretical but also in practical terms, how we effectuate or prevent changes towards a more sustainable supply of energy and transport fuel. As in analytical heuristics, it is not possible to offhand separate power with, power to, and power over in empirical research. These categories shine multiple lights on different aspects of the same empirical phenomena. In practice, these forms of power exercise are mostly interrelated. My less concern is to weigh and compare the pros and cons of each perspective, but rather to outline an agenda for a multidimensional analysis of all three mechanisms of power and their interrelations.

In order to get the full picture of how change happens, we should understand how different perspectives add on to each other (besides overlaps and contradictions). To do this, I will begin by describing each perspective in itself. Based on a survey on biofuel research, I will give references for each perspective. These references are only illustrative. Then, I will exemplify the interrelations between each of these perspectives with respect to biofuel research. I explain how power imbalances can affect processes of power with and power to. Again, scholars have demonstrated how large conglomerates have manipulated biofuel governance in their favor, and why therefore the biofuels boom should be considered as a gold rush. However, I argue that interrelations may also work the other way around, and this is particularly relevant to the main argument of this article. Biofuels as a creative alternative and a sustainable innovation may also provoke changes in existing relations of power over and contribute to address asymmetries and inequalities in agrifood and transport systems. We need a multidimensional power approach to explore these interrelations.

\section{Biofuel: sustainable innovation (power with)}

Research on biofuel governance and other studies in the field of sustainability are most often based on a positive perception of power in the sense of power with. Power with is a term that refers to processes of developing shared values, finding common ground, and generating collective strengths [2]. This conception does not necessarily refer to the diffusion of already existing (predefined) norms. Rather, power with implies learning processes that allow actors to question self-perceptions and to actively build up a new awareness of individuals or groups $[23,24]$. In this vein, with regard to biofuels, scholars have assumed that collective empowerment and solidarity are possible and that biofuel technologies as a "sustainable innovation" can pave the way to postcarbon societies $[25,26]$.

Power with is often linked to Arendt's definition of power [27]. ${ }^{2}$ According to Arendt, power always refers to a group or to a collective of individuals:

Power corresponds to the human ability not just to act but to act in concert. Power is never the property of an individual; it belongs to a group and remains in existence only so long as the group keeps together. When we say of somebody that he is 'in power' we actually refer to his being empowered by a certain number of people to act in their name ([28]: 44). ${ }^{3}$

Research on environmental leadership (e.g., [29]) in pioneer countries, such as Germany and France in the biofuel sector $[3,30]$, most obviously reflects such an understanding of power. Leaders or pioneers are empowered to act in the name of others from this perspective (while they dominate others from a perspective of power over, see below). In this sense, (Young [31]: 285) defines leadership in the interest of common welfare: 
Leadership (...) refers to the actions of individuals who endeavor to solve or circumvent the collective action problems that plague the efforts of parties seeking to reap joint gains in processes of institutional bargaining.

Leaders and pioneers do not enforce their own interests against or over others; rather they seek "to reap joint gains" of environmentalism. Environmental leadership studies, based on such an understanding of power, usually follow the discourse of Ecological Modernization that highlights flexible and cost-efficient problem solving. Ecological modernization outlines a win-win storyline of environmental protection that benefits green (biofuel) business as much as the environment [32, 33]. From this perspective, those who are neither leaders nor pioneers are considered free-riders or laggards, rather than subordinates. Non-leaders also benefit, at least in the long run, from power (with), since biofuels are expected to tackle common problems, such as climate change, enhance energy security, and to contribute to regional development [3, 34]. Policies promoting biofuels are hence per se seen to be desirable since, from this perspective, they serve everybody's interest.

Scholars have extensively analyzed the emergence, diffusion, efficiency, and effectiveness of policies promoting biofuels, with the (at least implicit) aim to foster their adoption and implementation [30, 35]. In this context, policy learning and experiments have been gaining momentum $[9,26]$. Deliberative processes, including third-party certification schemes, were initiated and observed with the aim to introduce sustainable biofuel production schemes that would integrate those formerly excluded stakeholders with new technology; in everyday practice, every actor in the field would then become a winner [4, 36].

Scholars who share this perspective of power as power with do not think in dichotomies such as winners-losers or good-bad. Instead, they understand power (or similar concepts, such as leadership) as serving the common good (climate protection, energy security, and sustainability). As there are no subordinates from this power perspective, no imperative follows to empower or to resist. The empowerment of non-leaders is not an issue because scholars assume that, in principle, they are also interested in developing sustainable innovations and that they likewise benefit from respective leadership efforts.

\section{Biofuel: creative alternative and "green" resistance (power to)}

While power with pertains to collective empowerment and solidarity, power to refers to single actors and separate groups, such as farmers, co-operatives, and individual processors who were initially key players in pioneering biofuel regions [19]. Accordingly, biofuels are often seen as an opportunity to empower green ideas and values. Pitkin [6] emphasizes how power can be non-relational, since an actor may have the power to accomplish something all by him- or herself. This understanding of power is related to the development of an individual identity; self-confidence and consciousness raising [23]. It is here where Nussbaum's and Sen's [37] capability approach comes in, which defines power as "a capability to act upon one's environment" [38]. For example, an individual farmer can simply start to produce and use biomass-based fuels without any permission or interference from another actor, such as the petrol industry. However, constructivist research has demonstrated how every actor or group is defined through socially constituted relations that, at least indirectly, shape the actions of individuals [7]: only a farmer who receives knowledge about alternative technologies may effectively implement them.

Power to can be linked to Parsons' definition of power as the ability "to get things done" [5]. It highlights a productive agency, especially in the cases where actors' goals are opposed or resisted. Biofuel research by small farmers and rural communities is often based on this perception of power $[9,39]$. Scholars highlight the potential of biofuels for rural development by providing new markets for agricultural production. They assume that through the introduction of radically new technologies in niches, farmers are able to empower themselves in an attempt of an "agro-ecological revolution" [8]. They highlight the self-empowering agency of hitherto marginalized people to become "energy sheiks" [40], based on biomass production.

Scholars, who take a perspective of power to, focus on the productive agency of the biofuel sector. They are interested in the empowerment of alternative ideas and values which, in the case of biofuels, allow for transforming fossil fuel-dependent societies. These alternative agents criticize the practices or the authority of the dominant, carbon-intense system and refuse to reproduce their own positions in this system. Their non-conformism is perceived to serve the common good as they develop alternative technologies required by everyone in a world beyond petrol. From a perspective of power to and in difference to a perspective of power with, there are only a limited number of transformational agents: not everybody in the field is assumed to be a "winner" in the first place; there are only a few "energy sheiks". However, scholars see an imperative to act based on normatively prior "green" values, for example, climate protection and sustainability (and everybody benefits from the realization of these values). 


\section{Biofuel: gold rush (power over)}

Scholars who explicitly issue power in the context of biofuels usually perceive power as asymmetric. Biofuel governance is seen as a zero-sum game which produces winners and losers. From this perspective, powerful actors, structures, and discourses in the field of biofuel governance influence the actions and even the thoughts of others. In the following, I will illustrate this perspective, further differentiating the "four faces" of power over (see Table 1): visible, hidden, invisible, and unconscious power $[2,41]$. (the fourth dimension does not understand power as a zero-sum game and can also be added to power to, see the first footnote.)

In the first dimension, agents exercise visible power when they directly influence political decision-makers based on their material and ideational resources [42]. What is visible is not the power as such, but rather its physical means such as lobbying activities, party financing, and armed force. (Dahl [10]: 201) defines: "A has power over $\mathrm{B}$ to the extent that he can get $\mathrm{B}$ to do something that B would not otherwise do" (emphasis added). Any kind of state force implementing objectives of sustainability by top downregulation means exercising direct power. Non-state actors may also play a role in this game. Coase [43] explains this for business firms.
Also when Pilgrim and Harvey [44] demonstrate how NGO lobbying significantly affected biofuel policy changes and sustainability regulation in the UK and in Europe, they assume that NGOs enforce their ideas against others in an arena of obviously competing demands.

The second dimension of hidden power refers to power not obviously opposed by anyone. Bachrach and Baratz [11] speak of "two faces of power" emphasizing that some issues never even make it onto the political agenda and are dismissed before observable negotiations start. For a long time, the EU issued biofuels only in the context of climate change, completely neglecting aspects of competing food demands and land use change in the Global South [45, 46]. Scholars demonstrating such hidden aspects apply this second dimension of power over to analyze biofuel governance.

The traditional conception of structural (hidden) power in international relations aims to address the coercion resulting from the capital mobility of transnational corporations. Threats to shift investments abroad do not even need to be voiced in order to influence policies in their favor [42, 47]. More recent studies point to the fact that businesses also exercise structural power by self-regulation and public-private partnerships;

Table 1 Different lenses of power on biofuels

\begin{tabular}{|c|c|c|}
\hline & Perception of biofuels & Definition \\
\hline Power with & $\begin{array}{l}\text { Sustainable innovation: } \\
\text { certification processes leading to win-win situations }\end{array}$ & $\begin{array}{l}\text { "Power with refers to processes of finding common } \\
\text { ground among diverse interests, developing shared } \\
\text { values and creating collective strength by organizing } \\
\text { with each other (Partzsch and Fuchs [70]: 363)." }\end{array}$ \\
\hline Power to & $\begin{array}{l}\text { Creative alternative: } \\
\text { marginalized farmers empowering through biofuel production }\end{array}$ & $\begin{array}{l}\text { "[A person] may have power to do or accomplish } \\
\text { something by himself, and that power is not } \\
\text { relational at all; it may involve other people if what } \\
\text { he has power to do is a social or political action, } \\
\text { but it need not (Pitkin [6]: 276-77)." }\end{array}$ \\
\hline
\end{tabular}

Power over

Visible power (first dimension)

Hidden power (second dimension)

Neglect of issues related to biofuel policies, such as competing food demands and land use change

Gold rush:

lobbying activities and party financing to promote biofuels
Manipulation of biofuel discourse by linking it only to public concerns about climate change and energy security
"A has power over B to the extent that he can get $B$ to do something that B would not otherwise do (Dahl [10]: 201)."

"Power is also exercised when A devotes his energies to creating or reinforcing social and political values and institutional practices that limit the scope of the political process to public consideration of only those issues which are comparatively innocuous to $A$. To the extent that A succeeds in doing this, B is prevented, for all practical purposes, from bringing to the fore any issues that might in their resolution be seriously detrimental to A's set of preferences (Bachrach and Baratz [11]: 948)."

"A may exercise power over B by getting him to do what he does not want to do, but he also exercises power over him by influencing, shaping, or determining his very wants (Lukes [12], 23)."

"Lukes plus Foucault" (Guzzini [71]: 23): A and B are subordinates to discourses that make them continuously reproduce system and positions 
these types of governance allow business actors to actively set rules, for example, for the "sustainable" production of biofuels at the expense of state actors [42, 48]. In addition, as public authorities have faced challenges in facilitating the implementation of their sustainability criteria outside their jurisdictions, the EU has started to use these private schemes to verify compliance with sustainability criteria in biofuel production outside its own territory [49, 50]. As a result, following this perspective, power in the global political economy has been diffused, leaving biofuel conglomerates with considerable power over others [51].

Further, scholars are increasingly focusing on power relations linked to latent conflicts of interest. In the third dimension, invisible power comes to play as a result of norms and ideas [41]. Research analyzes discourses, communication practices, cultural values and institutions, which all work to shape relevant thoughts and actions [12]. With regard to biofuels, Munro [22] has shown how, in the United States, a powerful coalition of agricultural interests manipulated the governance of biofuels by linking it to public concerns about climate change and energy security. In consequence, corn biofuel received political support, tax reductions, and subsidies. Likewise, Puttkammer and Grethe [52] have found a coalition of biofuel advocates to dominate the public discourse in Germany, while scientists who doubted the efficiency of biofuels could not make their voice heard. The discourse only shifted with the 20072008 food price crisis when scholars demystified the "ethanol bubble" [53] and outlined potentially devastating implications for global poverty and food security. Experts, NGOs, and business actors who have challenged the sustainability of biofuels on many fronts began to be heard $[20,22]$.

For the most part, these discourse scholars blame other scholars who apply a perspective of power with for neglecting and postponing important questions of social justice linked to biofuel production [21, 54]. Win-win rhetoric is demonstrated to manifest global power asymmetries rather than to contribute to more ecology and fairness [22, 53]. From this perspective, pioneers and leaders, whose role Young [31] and Bernard and Prieur [30], among others, consider to be positive, only serve dominant interests and prevent a more fundamental social transformation to sustainability. With reference to the International Political Economy, most scholars deny a simple confrontation of biofuel proponents (or pioneers) and opponents (or laggards). In this vein, Levidow [55] outlines how the EU can continue "its global plunder of resources" because it pursues global leadership for sustainable biofuels. Silva-Castaneda [56] demonstrates how, in Indonesia, some NGOs decided to participate in the Roundtable on Sustainable Palm Oil (RSPO), a certification process initiated by the WWF, among others. The local NGOs managed to include important clauses regarding indigenous and land rights in the RSPO standard. In practice, however, auditors rarely recognize as valid evidence the forms of proof put forward by local communities, and global conglomerates could even use the standards to increase their primacy vis-à-vis local farmers [56]. These examples reveal power over within multi-stakeholder processes.

Studies demonstrate that the expansion of biofuels in countries of the Global South was only possible through the partial neglect (simplification) of their cultural and ecological diversity [57]. Nygren [58] illustrates how leading retailers, in negotiation with environmental organizations, have guided consumers' expectations of certified Southern forest products by building images of Southern community forest producers as authentic and exotic others. She concludes that certification as a market-based form of governance has only had a limited impact on altering the unequal relationship characteristic of global networks of production and consumption.

With reference to Foucault [13] and Bourdieu [59], we can capture links between knowledge, power, and politics in a fourth dimension of power over [17]. Critical and (post-) structuralist approaches understand power in a way that everything is socially constructed. Scholars analyze the normative impact on (supposed) losers, such as farmers in the Global South, as well as on (supposed) winners, such as major agribusiness actors. All actors work to mainly reproduce systems and positions [60]. With regard to biofuels, several studies have highlighted the central role of knowledge and framing [15, 16, 21]. Drawing on Foucault, Kuchler and Linnér [21] have analyzed the discursive practices of the three major international organizations focused on food and agriculture, energy, and climate with regard to biofuels over the last 20 years: the UN Food and Agriculture Organization (FAO), the International Energy Agency (IEA), and the Intergovernmental Panel on Climate Change (IPCC). They found that, in contrast to pro and contra accounts, the arguments of all three organizations reflected a policy consensus based on the mainstream notion of industrial agricultural production, promoting the intensification and expansion of rural production. The biofuel discourse has further constituted a concatenation of the three issues of agricultural production, energy security, and climate change mitigation. When the discourse shifted with the 2007-2008 food price crisis, all the three major organizations adapted to this shift [21]. Instead of exercising power over by manipulating discourses on biofuels according to specific pro or contra interests, the organizations were found to rather reproduce hegemonic discourses and their own positions. 
The gold rush metaphor is used a lot to describe the situation of biofuels from a power over perspective [1]. Biofuel production, like gold mining, is unprofitable for most farmers, just like it was for diggers and mine owners. Both biofuel production and gold mining can in addition have very negative environmental effects. While, however, people are made to believe that everyone can become abundantly wealthy ("energy sheiks"), only some few investors make large fortunes. Applying discursive approaches of power over, we can argue that even such investors and major businesses are subject to and not only conscious manipulators of discourses of agricultural intensification and economic growth. The analysis of power over helps to understand why change to more sustainable transport and agricultural systems does not happen. However, as I argue in this article, it falls short on explaining when and why there also sometimes is disruptive change and empowerment.

\section{Power to change: interrelations between power with, power to, and power over}

While the perspectives of power with and power to (over-) emphasize the potential for change with regard to biofuels, scholars with understandings of power over often exaggerate their negative impacts. The tripartite framework allows for the combining of different analytical perspectives and to examine their interrelations. While the three categories are first of all analytical heuristics, they also stand for different mechanisms of the exercise of power (see Fig. 1). Power over affects what is considered a "sustainable innovation" and "creative alternative". Research has demonstrated this. However, I argue that it is also possible the other way round: there are situations in which power with and power to can address power imbalances and prevent a situation in which there are only a few winners and many losers as a result of biofuel governance.
As shown in Fig. 1, besides considering material and ideational sources of power, we also need to consider different mechanisms of power (over/to/with), since they lead to different results of power (leading to a new distribution of sources in a circular process, see the arrow at the bottom of Fig. 1). Biofuels per se are neither a sustainable innovation, a creative alternative nor a gold rush. The three metaphors exemplify three different results of power: the exercise of power over leads to a gold rush situation. So, if scholars only ask for power over, they will always find winners and losers. By contrast, if we ask for the exercise of power to, we may find that biofuels are creative alternative. Finally, the exercise of power with can be exemplified by a case of finding an agreement on sustainability criteria of biofuel production. To demonstrate overlaps, especially, in terms of the results of power, I used dashed lines in Fig. 1.

When, in the field of biofuels, scholars explicitly issue power, they generally use concepts of power over to explain why governance and research in this field have a blind spot for power asymmetries $[49,53]$. Biofuel opponents may have accomplished a shift in the biofuel discourse after the 2007-2008 food price crisis [20, 22]. However, overriding power asymmetries have prevented a structural change in both the energy/transport and the agricultural sectors. The trend is now definitely towards large companies and conglomerates $[49,50]$.

However, the fact that biofuels have caused no structural change and have disadvantaged rather than empowered small farmers in the Global South, does not mean that a structural change is impossible. What I want to argue in this article is that exercising consensual forms of power (power with) as well as selfempowerment and resistance (power to) can also eclipse and overcome power asymmetries (power over). Empirical research on deliberative processes suggests that communication and common action never happen

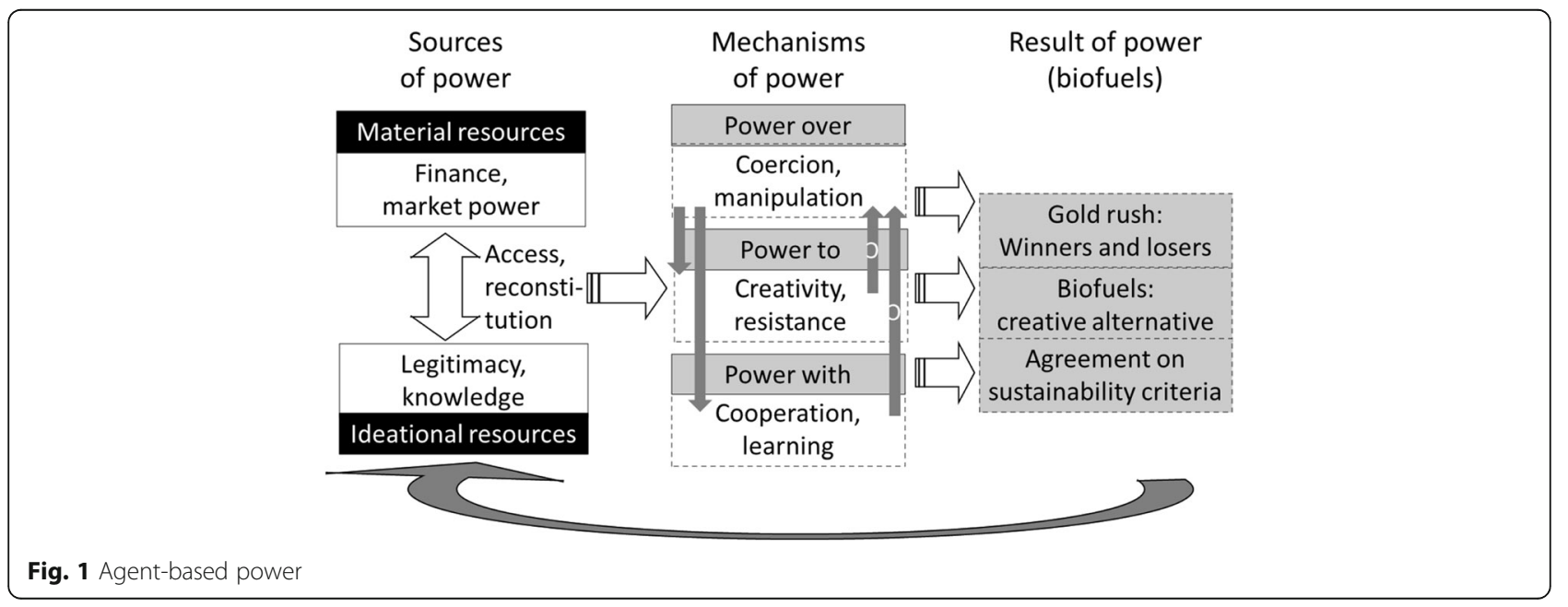


among equals and that they are never free from any form of power over [36, 61]. Hence, we need to understand power with as a form of exercising power, which is strategic (bargaining) as well as communicative (arguing). A crucial part of this process is the orientation of agents involved in processes of biofuel governance. If actors are open to changing their positions and developing shared understandings, transitions to sustainability can follow from dialogues [61, 62].

Following this perspective, even if small farmers in the Global South have fewer capabilities compared to conglomerates from the EU and the United States, this does not mean that they have no possibility to act independently from them. For example, sugar is costly to establish, and thus is economically most efficient at large plantation scales. However, Jatropha can more readily be produced through outgrower schemes as it is less capital intensive $[9,49]$. While currently almost all bio-ethanol is produced from grain or sugarcane and therefore competes with food purposes, other efficient and economically viable technologies for ethanol production are available [63]. The production of perennial energy crops, such as grasses and trees, and crop residues, such as straw, are seen to require fewer inputs and less prime land [64].

Under specific conditions, empowerment is possible; processes of power with and power to can have a (positive) impact on unwanted relations of power over. For example, processes of stakeholder dialogue and certification demonstrate that an agreement beyond the lowest common denominator is possible. In addition, they can weaken the perceived legitimacy of powerful actors that are producing biofuels unsustainably. The critical discourse on biomass certification has issued consumers' accountability for harmful social and environmental effects in countries of production $[55,65]$. When the legitimacy of unconditional import as well as of private certification schemes was put into question [50], transnational conglomerates lost ideational and material resources on which their power over others was based. In the agrifood sector, we can clearly see that certification has become a new normative obligation [66].

We can observe various kinds of empowerment and resistance related to biofuels. While Nygren [58] argues that certification schemes reproduce (inferior) positions of southern producers as authentic and exotic others, she does not completely deny that certification had a positive impact on altering asymmetries in global networks of production and consumption. Silva-Castaneda's [56] study discloses new ways in which local communities can legally prove their land rights, for instance, by video documentation to replace missing formal documents or destructed land marks.

Scholars have described movements, such as Via Campesina, in terms of exercising power over and opposing transnational agriculture corporations [67]. In terms of reducing and overcoming power asymmetries, however, what is most striking is the fact that small farmers within this movement exercise power to by doing healthy and sustainable agriculture independently of the major agribusinesses to which, from a power over perspective, they would only be subordinated. At the same time, when producing organically, small farmers do not reproduce the system of industrial agricultural production (and their inferior positions within that system). So, their way of farming can be considered as a creative alternative and as a way of resistance. Moreover, within this movement of Via Campesina, despite widely different internal cultures, farmers also exercise power with by (re-) constituting a new shared peasant identity. From a perspective of power with, we can argue that, in the long run, everybody, even from outside this movement, may benefit and share norms and values developed here such as sustainability in farming. The movement delegitimizes the acquisition of land by established conglomerates ("land grabbing"), whose ideational sources of power shrink in consequence. The visible result is a new, more equal, and just distribution of (power) resources through land reforms.

\section{Conclusions}

This article should not only encourage a debate on power issues with regard to biofuels, but moreover, develop the debate more comprehensively. When political power has been analyzed in the context of biofuels, this has happened so far through using confrontational or structuralist and discursive approaches that are based on an understanding of power over. Respective scholars have accused other researchers of neglecting "real power concentrations" in the biofuels industries. Often quite rightly: biofuel research has neglected the limits of winwin for a very long time. Scholars have taken sides and normatively inflated their own pro biofuel position, while they have dispatched their adversaries as laggards with regard to the future of transport and agriculture. Of course, not every (supposedly) sustainable innovation is necessarily good in the sense that it is completely uncontroversial (even if there is no visible opposition as in the case of biofuels for a long time). In this context, the question of power essentially addresses the repoliticization of decisions perceived to be urgent and without alternative. With the 2007-2008's shift in discourse, critics re-politicized the governance of biofuels. Several farmer associations have completely turned against biofuels. I argue that this rejection of biofuels is due to a limited perception of power as power over.

Why does it make sense to complement such a perception of power over? Why does a multidimensional power framework make more sense? Naming different 
perspectives, as done here, with one and the same term-"power"-means, first, to put them on one normative level. Gold rush (power over) is a term with strongly negative connotations, on the one hand, and leads to normatively inflating sustainable innovations (power with) and creative resistance (power to), on the other. This is often unjustified because the exercise of power with and power to are not per se more legitimate forms of achieving social change. For example, preventing greenhouse gas emissions "from above" can be quite legitimate.

Secondly, as illustrated in this article, all three conceptions of power are already used in research on biofuels (although sometimes only implicitly; this should change). My hope is that this article addresses diverse communities and overcomes boundaries between them with this multidimensional power approach (in particular, between those who still celebrate biofuels as a "sustainable innovation" and those scholars who completely condemn them because of related power asymmetries). Especially those whose research is (implicitly) based on understandings of power as power with and power to could take stronger reference to researchers taking a critical viewpoint on their studies (power over)-in particular, through showing how consensual forms of power exercise (power with) and resistance and empowerment (power to) not only reproduce power asymmetries but also help overcome them. If we look at the gold rush metaphor from a perspective of power to, we may see that there is a lot of entrepreneurship involved in the discovery of gold deposits. From the perspective of power with, we may also see that people in the field of gold mining as well as of biofuel production find common ground among diverse interests and organize with each other.

Third, convincing and learning (power with) as well as creative ability (power to) and coercion and manipulation (power over) do not completely capture concrete change processes. The analytical categories applied in this paper help to cluster the various understandings of power in biofuel research, but they also reflect different mechanisms of power in reality. Power with perspectives focus on the benefits of biofuels (sustainable innovation); power to focuses on how new actors develop alternatives to fossil (and nuclear)-based economies; power over points to the limits of change because of the dominance of specific actors, structures, and discourses. The common terminology allows that the three perspectives on power are not considered as mutually exclusive (different interpretations of the same phenomenon), but as supplementary (different aspects of a change process). It becomes possible to examine their interrelations and their supplementary potential. With this article, I hope to have given an impetus for further research in this direction. A comprehensive analysis of power in diverse parts of biofuel research and governance is definitely a prerequisite for more seriously and intensively exploring questions of where, when, and how the governance of biofuels may also allow for "green" resistance and collective empowerment.

\section{Endnotes}

${ }^{1}$ If actors create (reproduce) discourses and structures, I call this power to. Most constructivist studies however deal with identifying dominant (hegemonic) structures and discourses over others that are unconsciously reproduced, i.e., power over.

${ }^{2}$ Power with is not identical to Arendt's understanding of power or its empirical operationalization hardly accomplishes Arendt's demands. So deliberative theories of democracy build upon her understanding of power without finding it comprehensively implemented in reality $[61,68,69]$. In difference to deliberative processes, power with encompasses communicative as well as common action.

${ }^{3} \mathrm{An}$ example, to which Arendt refers in a footnote to her definition of power, is the student protests at Berkeley and elsewhere at the end of the 1960s. She contrasts the power of the students-"obviously the strongest power on every campus simply because of the students' superior number" ([28]: 44) — to the violence of the university authorities. An individual student leader 'in power' would speak on behalf of the movement.

\section{Acknowledgements \\ The research received no funding.}

\section{Competing interests}

The author declares that she has no competing interests.

\section{Publisher's Note}

Springer Nature remains neutral with regard to jurisdictional claims in published maps and institutional affiliations.

Received: 1 February 2017 Accepted: 4 May 2017

Published online: 18 May 2017

\section{References}

1. Balkema A, Pols AJ (2015) Biofuels: sustainable innovation or gold rush? Identifying responsibilities for biofuel innovations. In: Koops B-J, Oosterlaken I, Romijn $\mathrm{H}$ et al (eds) Responsible innovation 2: concepts, approaches, and applications. Springer, New York, pp 283-303

2. Partzsch L (2015) Kein Wandel ohne Macht-Nachhaltigkeitsforschung braucht ein mehrdimensionales Machtverständnis. GAIA 24(1):48-56

3. Sordaa G, Banseb M, Kemfert C (2010) An overview of biofuel policies across the world. Energy Policy 38(11):6977-6988

4. Vermeulen S, Dufey A, Vorley B (2008) Biofuels: making tough choices. The International Institute for Environment and Development (IIED) (2)., pp 1-2

5. Parsons T (1963) On the concept of political power. Proc Am Philos Soc 107(3):232-262

6. Pitkin HF (1985) Wittgenstein and justice: on the significance of Ludwig Wittgenstein for social and political thought. University of California Press, Berkeley 
7. Barnett M, Duvall R (2005) Power in global governance. In: Barnett MN, Duvall $R$ (eds) Power in global governance. Cambridge University Press, Cambridge, pp 1-32

8. Altieri MA, Toledo VM (2011) The agroecological revolution in Latin America: rescuing nature, ensuring food sovereignty and empowering peasants. J Peasant Stud 38(3):587-612

9. van Eijcka J, Romijn H (2008) Prospects for Jatropha biofuels in Tanzania: an analysis with strategic niche management. Energy Policy 36(1):311-325

10. Dahl RA (1957) The concept of power. Behav Sci 2(3):201-215

11. Bachrach P, Baratz MS (1962) Two faces of power. Am Polit Sci Rev 4(56): 947-952

12. Lukes S (1974) Power: a radical view. Macmillan, London

13. Foucault M (1982) The subject and power. Crit Inq 8(4):777-795

14. Laclau E, Mouffe C (1985) Hegemony and socialist strategy: towards a radical democatic politics. Verso, London

15. Baka J (2014) What wastelands? A critique of biofuel policy discourse in South India. Geoforum 54(6):315-323

16. Hunsberger C (2010) The politics of Jatropha-based biofuels in Kenya: convergence and divergence among NGOs, donors, government officials and farmers. J Peasant Stud 37(4):939-962

17. Digeser P (1992) The fourth face of power. J Polit 54(4):977-1007

18. Haugaard M (2012) Rethinking the four dimensions of power: domination and empowerment. J Polit Power 5(1):33-54

19. Hunt SC, Sawin JL, Stair P (2006) Cultivating renewable alternatives to oil. In: Worldwatch Institute (ed) State of the world 2006: Special focus: India and China. Earthscan, London, pp 61-77

20. Sengers F, Raven R, van Venrooij A (2010) From riches to rags: biofuels, media discourses, and resistance to sustainable energy technologies. Energy Policy 38(9):5013-5027

21. Kuchler M, Linnér B-O (2012) Challenging the food vs. fuel dilemma: genealogical analysis of the biofuel discourse pursued by international organizations. Food Policy 37(5):581-588

22. Munro B (2015) The lost innocenece of ethanol: Power, knowledge, discourse, and the U.S. biofuel policy: Doctoral dissertation. Kansas State University, Kansas

23. Eyben R, Harris C, Pettit J (2006) Introduction: exploring power for change. IDS Bull 37(6):1-10

24. Gaard G (2010) Women, water, energy: an ecofeminist approach. In: Brown PG, Schmidt JJ (eds) Water ethics: foundational readings for students and professionals. Island Press, Washington, DC, pp 59-75

25. Balat M, Balat $H$ (2009) Recent trends in global production and utilization of bio-ethanol fuel. Appl Energy 86(11):2273-2282

26. Nill J, Kemp R (2009) Evolutionary approaches for sustainable innovation policies: from niche to paradigm? Res Policy 38(4):668-680

27. Allen A (1998) Rethinking power. Hypatia 13(1):21-40

28. Arendt H (1970) On violence. Harcourt, Brace \& World, New York

29. Skodvin T, Andresen S (2006) Leadership revisited. Glob Environ Polit 6(3): $13-27$

30. Bernard F, Prieur A (2007) Biofuel market and carbon modeling to analyse French biofuel policy. Energy Policy 35:5991-6002

31. Young OR (1991) Political leadership and regime formation: on the development of institutions in international society. Int Organ 45(3): 281-308

32. Huber J (2000) Towards industrial ecology: sustainable development as a concept of ecological modernization. J Environ Policy Plan 2(4):269-285

33. Jänicke M (2008) Ecological modernisation: new perspectives. J Clean Prod 16(5):557-565

34. Bomb C, Deurwaarder E, Kaberger T (2007) Biofuels for transport in Europe: lessons from Germany and the UK. Energy Policy 35(4):2256-2267

35. Foxona T, Pearson P (2008) Overcoming barriers to innovation and diffusion of cleaner technologies: some features of a sustainable innovation policy regime. J Clean Prod 16(1):S148-S161

36. Longstaff $\mathrm{H}$, Secko DM (2014) Assessing the quality of a deliberative democracy mini-public event about advanced biofuel production and development in Canada. Public Understanding of Science (online)., pp 1-10

37. Nussbaum M, Sen AK (1987) Internal criticism and Indian rationalist traditions. World Institute for Development Economics Research of the United Nations University, Helsinki

38. Scholtes F (2009) Analysing and explaining power a capability perspective, Bonn
39. Malik US, Ahmed M, Sombilla MA et al (2009) Biofuels production for smallholder producers in the Greater Mekong Sub-region. Appl Energy 86(S1):S58-S68

40. Rathke G-W, Diepenbrock W (2006) Mit Biomasse zum 'Energie-Scheich'?: Stand, Ertragspotenziale und Perspektiven. Chancen für Landwirtschaft und angrenzende Industriezweige. In: DLG (ed) (Deutsche LandwirtschaftsGesellschaft) Zukunftsstandort Deutschland: Strategien Für Die Landwirtschaft. DLG-Verlag, Frankfurt a.M

41. Gaventa J (2006) Finding the spaces for change: a power analysis. IDS Bull 37(6):23-33

42. Fuchs D (2005) Understanding business power in global governance. Nomos, Baden-Baden

43. Coase RH (1988) The firm, the market, and the law. University of Chicago Press, Chicago

44. Pilgrim S, Harvey M (2010) Battles over biofuels in Europe: NGOs and the politics of markets. Sociol Res Online 13(3):4

45. Stattman SL, Gupta A (2015) Negotiating authority in the global biofue governance: Brazil and the EU in the WTO. Glob Environ Polit 15(1):41-59

46. Afionis S, Stringer LC (2012) European Union leadership in biofuels regulation: Europe as a normative power? J Clean Prod 32(1):114-123

47. Altvater E, Mahnkopf B (1999) Grenzen der Globalisierung: Ökonomie, Ökologie und Politik in der Weltgesellschaft, 4th edn. Westfälisches Dampfboot, Münster

48. Levin K, Cashore B, Koppell J (2009) Can non-state certification systems bolster state-centered efforts to promote sustainable development through the clean development mechanism? Wake Forest Law Review 44(1):777-798

49. Dauvergne P, Neville KJ (2010) Forests, food, and fuel in the tropics: the uneven social and ecological consequences of the emerging political economy of biofuels. J Peasant Stud 37(4):631-660

50. Ponte S, Daugbjerg C (2015) Biofuel sustainability and the formation of transnational hybrid governance. Environ Polit 24(1):96-114

51. Henriksen LF (2015) The global network of biofuel sustainability standardssetters. Environ Polit 24(1):115-137

52. Puttkammer J, Grethe H (2015) The public debate on biofuels in Germany: who drives the discourse? Ger J Agric Econ 64(4):263-273

53. Runge CF, Senauer B (2007) How biofuels could starve the poor. Foreign Aff 86(3):41-53

54. Horlings LG, Marsden TK (2011) Towards the real green revolution? Exploring the conceptual dimensions of a new ecological modernisation of agriculture that could 'feed the world'. Glob Environ Chang 21(2):441-452

55. Levidow L (2013) EU criteria for sustainable biofuels: accounting for carbon, depoliticizing plunder. Geoforum 44(1):211-223

56. Silva-Castaneda L (2012) A forest of evidence: third-party certification and multiple forms of proof-a case study of oil palm plantations in Indonesia. Agric Hum Values 29(3):361-370

57. Selfa T, Bain C, Moreno R et al (2015) Interrogating social sustainability in the biofuels sector in Latin America: tensions between global standards and local experiences in Mexico, Brazil, and Colombia. Environmental Management

58. Nygren A (2015) Governance and images: representations of certified southern producers in high-quality design markets. Environ Values 24(3): 391-412

59. Bourdieu P (1987) Sozialer Sinn: Kritik der theoretischen Vernunft. Suhrkamp, Frankfurt a.M

60. Guzzini S (1993) Structural power: the limits of neorealist power analysis. Int Organ 47(3):443-478

61. Dryzek JS (2000) Deliberative democracy and beyond: liberals, critics, contestations. Oxford University Press, New York

62. Prittwitz V (ed) (1996) Verhandeln und Argumentieren. Leske + Budrich, Opladen

63. Mussatto SI, Dragone G, Guimarães PM et al (2010) Technological trends, global market, and challenges of bio-ethanol production. Biotechnol Adv 28(6):817-830

64. Shortall O (2014) Rethinking bioenergy from an agricultural perspective: ethical issues raised by perennial energy crop and crop residue production for energy in the UK and Denmark: PhD thesis. University of Nottingham, Nottigham

65. Partzsch L (2011) The legitimacy of biofuel certification. Agric Hum Values 28(3):413-425

66. Kalfagianni A (2015) 'Just food': the normative obligations of private agrifood governance. Glob Environ Chang 31(1):174-186 
67. Martínez-Torres ME, Rosset PM (2010) La Vía Campesina: the birth and evolution of a transnational social movement. J Peasant Stud 37(1):149-175

68. Habermas J (1998) Between facts and norms: contributions to a discourse theory of law and democracy. MIT Press, Cambridge

69. Young IM (2001) Activist challenges to deliberative democracy. Polit Theo 29(5):670-690

70. Partzsch L, Fuchs DA (2012) Philanthropy: power with in international relations. J Polit Power 5(3):359-376

71. Guzzini S (2007) The concept of power: a constructivist analysis. In: Berenskoetter F, Williams MJ (eds) Power in world politics. Routledge, New York, pp 23-42

\section{Submit your manuscript to a SpringerOpen ${ }^{\bullet}$ journal and benefit from:}

- Convenient online submission

- Rigorous peer review

- Open access: articles freely available online

- High visibility within the field

- Retaining the copyright to your article

Submit your next manuscript at $\gg$ springeropen.com 